\title{
Conservation of the Okapi Wildlife Reserve, Zaïre
}

\author{
Peter J. Stephenson and John E. Newby
}

\begin{abstract}
The Okapi Wildlife Reserve was created in May 1992 to conserve a representative area of the Ituri rain forest in north-eastern Zaire. This article examines the threats facing this large protected area and summarizes the management actions proposed to address these problems within the next 10 years. Emphasis is placed on the need to integrate the local population into reserve management and to empower people as much as possible to manage their own resources. The long-term future of the reserve in the context of national economic and political instability is discussed.
\end{abstract}

\section{Introduction}

Zaïre is one of the most important countries in Africa for the conservation of biodiversity, with a larger area of tropical rain forest and more species of vertebrate than any other country on the continent (Doumenge, 1990; McNeely et al., 1990). The Ituri Forest in northeastern Zaire is one of the largest remnants of Congo Basin rain forest and represents a regional centre of biodiversity (e.g. Oates et al., 1987; Collar and Stuart, 1988; Stuart and Adams, 1990). In order to safeguard a representative area of the Ituri, on 2 May 1992 a ministerial decree created the Réserve de Faune à Okapi (Okapi Wildlife Reserve; OWR).

The OWR covers an area of $1,372,625$ ha $(13,726 \mathrm{sq} \mathrm{km})$ between $1^{\circ} 00^{\prime} \mathrm{N}$ and $2^{\circ} 29^{\prime} \mathrm{N}$, and $28^{\circ} 00^{\prime} \mathrm{E}$ and $29^{\circ} 04^{\prime} \mathrm{E}$, at an altitude of between 700 and $1000 \mathrm{~m}$ (Figure 1). Mixed moist semi-evergreen rain forest is the most diverse habitat in the OWR (Hart, 1985). This is interspersed with mbau forest, a rain forest characterized by the dominance of Gilbertiodendron dewerrei (Caesalpiniaceae). The rest of the reserve comprises secondary forest and swamp forest. Vertebrate species of conservation concern in the OWR (Table 1) include the okapi Okapia johnstoni, an endemic forest giraffe with a distribution centred on the Ituri (Verschuren, 1978; Hart and Hart, 1988). The
OWR contains at least 13 species of diurnal anthropoid primates, the highest diversity known from a single site in Africa (Hart et al., 1986; Thomas, 1991), and provides refuge for one of the largest populations of forest elephant Loxodonta africana cyclotis in Zaire (Alers et al., 1992). The Ituri is considered to be the third most important forest for bird conservation in mainland Africa (Collar and Stuart, 1988) and several key species are found in the OWR (Table 1).

Populations of hunter-gatherer pygmies, collectively known as the BaMbuti, have long lived in the Ituri Forest in association with indigenous Bantu and Sudanic-speaking shifting cultivators (Harako, 1976; Turnbull, 1961, 1983, 1986). Historically these populations have lived off the land and will require continued access to forest resources in the environs of the OWR. The challenge for reserve managers is to work with local communities to produce a mutually acceptable management system that allows for sustainable resource use while ensuring the long-term viability of forest ecosystems.

\section{Management of the OWR}

Protected areas in Zaïre are managed by the Institut Zairois pour la Conservation de la Nature (IZCN). The governing body (Direction Général) has its headquarters in 
Kinshasa. The OWR is managed from an IZCN reserve station at Epulu (Figure 2). In recent years, three non-governmental organizations (NGOs) have provided institutional support and technical assistance to IZCN in the Ituri: WWF (World Wide Fund for Nature), WCS (the Wildlife Conservation Society) and GIC (Gilman Investment Company). There is now an urgent need to establish an effective and coherent management system for the newly created reserve. Recently, management guidelines were produced to provide a framework to help set objectives and priorities over a 10-year period (IZCN/WWF, 1994).

This article outlines the threats facing the OWR and summarizes the proposed management actions required over 10 years to ensure long-term conservation of this important protected area.

\section{Threats to the Okapi Wildlife Reserve}

\section{Immigration}

Immigration is one of the greatest threats to the OWR (e.g. Peterson, 1990, 1991; Curran, 1992; IZCN/WWF, 1994). Of 156 village collectives where censuses were recently carried out in and around the reserve, 129 (83 per cent) exhibited some level of immigration among the Bantu population (B. Curran, unpublished data). Immigrants come from a variety of locations in Zaire. The main factors influencing people's resettlement include high population densities and a dearth of arable land in their home areas, coupled with an abundance of land, its ease of acquisition, and the lure of liberalized gold prospecting at the forest frontier (Peterson, 1991). Immigration control is complicated by ambiguous laws and

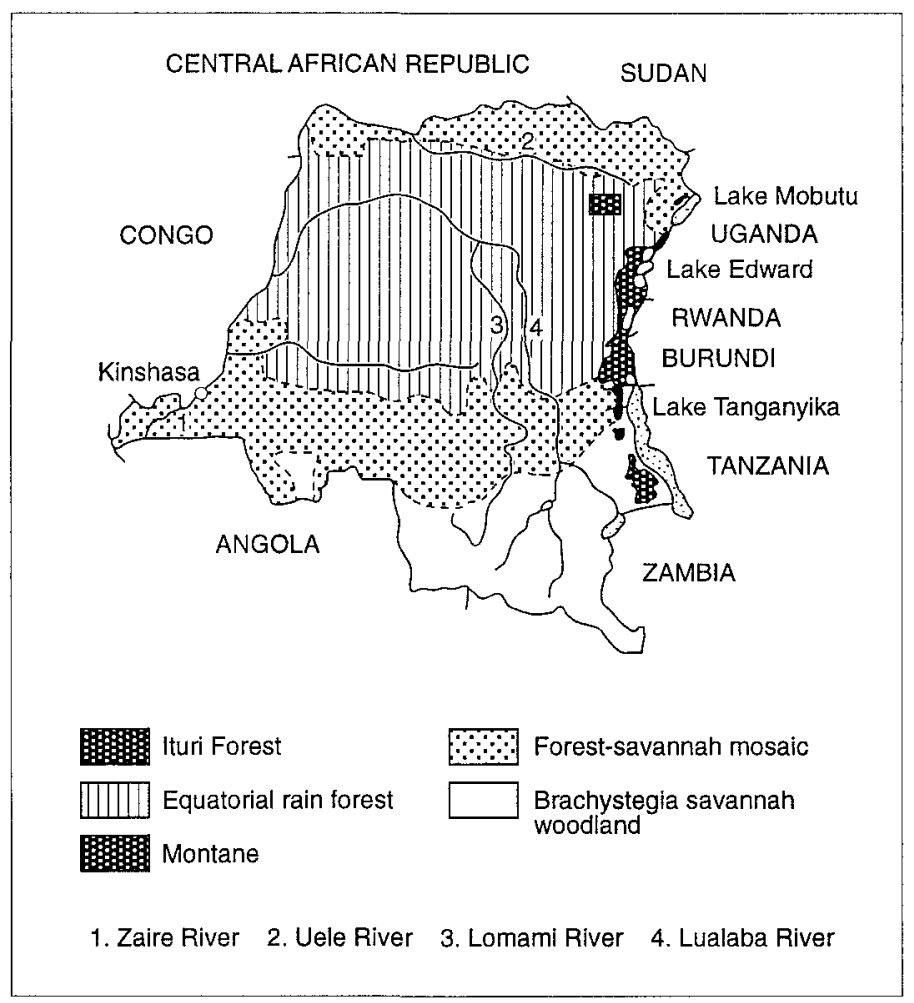

Figure 1. Map of Zaïre to show location of the Ituri Forest in relation to national vegetation zones. Adapted from Richter et al. (1990).

(C) $1997 \mathrm{FFI}$, Oryx, 31 (1), 49-58 


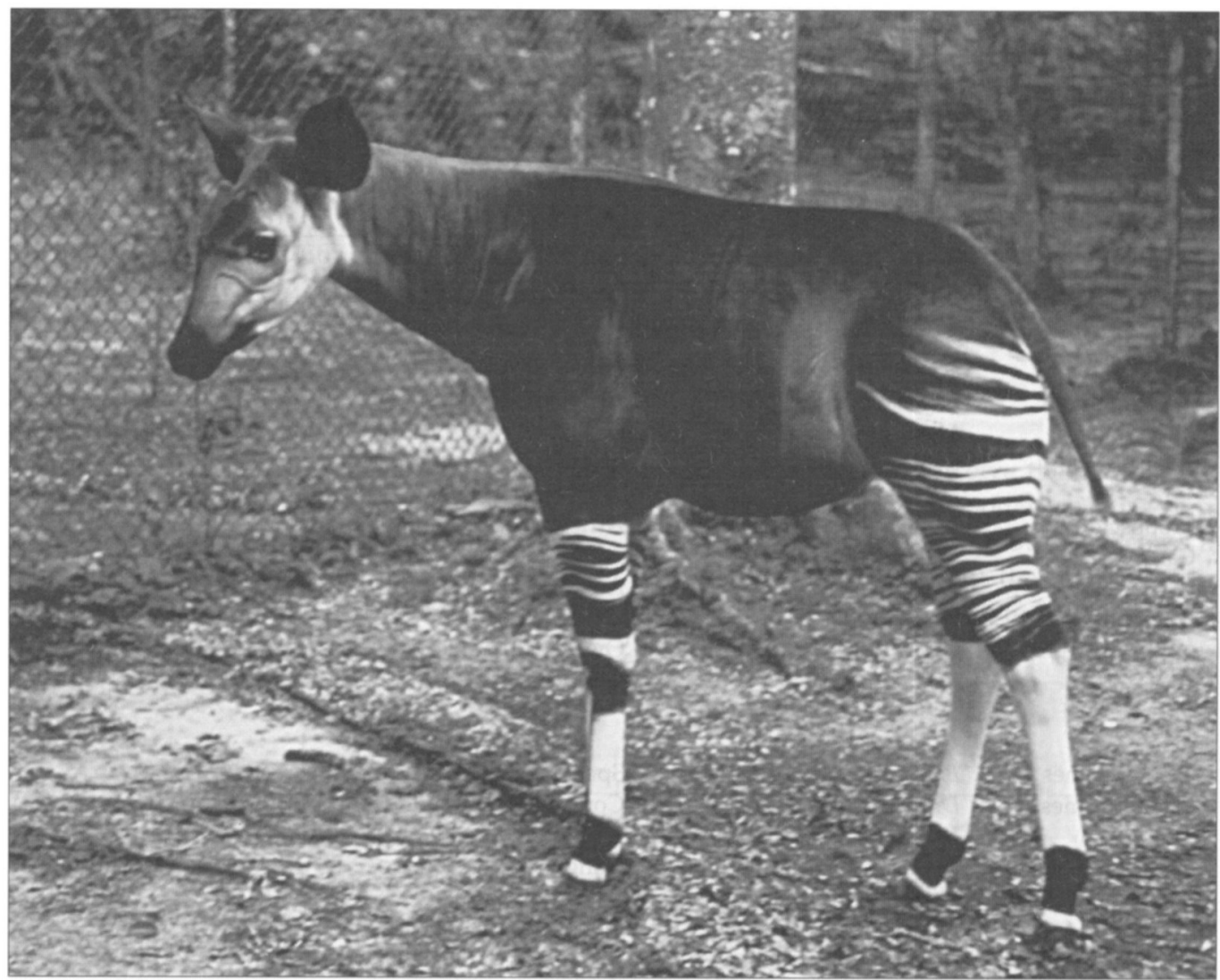

The okapi Okapia johnstoni, a forest giraffe endemic to Zaire, which is protected by the Okapi Wildlife Reserve (WWF/P. I. Stephonson).

continuing political instability in Zaire, which often makes law enforcement impossible. If the human population around the reserve continues to expand, it will place an ever-increasing demand on natural resources and reduce the likelihood of rational use.

\section{Forest clenrance}

Zairean forests in general are not in imminent danger from commercial logging because Zaire plays only a minor role in the international tropical hardwood trade (Grainger, 1993). However, throughout the country people continue to clear forest where and when they require land. Around the OWR, slash-and-burn agriculture is especially conspicuous along roads. Although uncontrolled deforestation is undesirable and illegal, the lack of land-use monitoring over recent years means that there is inadequate information to determine sites and rates of deforestation and its impact on reserve ecosystems.

\section{Illegal hunting}

People exploit the OWR as a source of game meat, even though it is illegal to hunt in the reserve. Several species are taken, including small forest antelopes and primates. Although subsistence hunting is probably having a minor impact on mammal populations, commercial hunting (to provide meat for sale in large towns) is expected to have a more significant effect, especially if techniques that are outlawed under the hunting act (Law 82-002), such as the use of firearms or wire snares, are employed. Forest elephants have been 
subjected to systematic ivory poaching by armed gangs. Poaching will continue to be a major problem because of the lack of accurate information on the level and impact of this activity, and the continued logistical difficulties facing IZCN in controlling it.

Table 1. Some mammal and bird species of conservation concern in the OWR

\begin{tabular}{|c|c|c|c|}
\hline Order & Species & English name & Status \\
\hline \multicolumn{4}{|l|}{ Mammals } \\
\hline Rodentia & Malacomys verschureni & & $\mathrm{K}$ \\
\hline Tubulidentata & Orycteropus afer & Ardvark & 1 \\
\hline Pholidota & Manis gigantea & Giant pangolin & 1 \\
\hline \multirow[t]{2}{*}{ Artiodactyla } & Okapia johnstoni & Okapi & 1 \\
\hline & Hyemoschus aquaticus & Water chevrotain & 1 \\
\hline Proboscidea & Loxodonta africana cyclotis & African forest elephant & $\mathrm{V}, 1$ \\
\hline \multirow[t]{2}{*}{ Carnivora } & Osbornictis piscivora & Aquatic genet & 1 \\
\hline & Profelis aurata & African golden cat & $\mathrm{K}, 1$ \\
\hline \multirow[t]{3}{*}{ Primates } & Cercopithecus l'hoesti & L'Hoest's monkey & $\mathrm{V}$ \\
\hline & Cercopithecus hamlyni & Owl-faced monkey & $\mathrm{V}$ \\
\hline & Pan troglodytes & Chimpanzee & $V, 1$ \\
\hline \multicolumn{4}{|l|}{ Birds } \\
\hline Ciconiiformes & Bostrychia rara & Spot-breasted ibis & (C) \\
\hline \multirow[t]{2}{*}{ Falconiformes } & Dryotriorchis spectabilis & Congo serpent eagle & (C) \\
\hline & Urotriorchis macrourus & Long-tailed hawk & (C) \\
\hline \multirow[t]{3}{*}{ Galliformes } & Afropavo congensis & Congo peacock & $\mathrm{K}$ \\
\hline & Agelastes niger & Black guineafowl & (C) \\
\hline & Francolinus nahani & Nahan's francolin & (R), $\mathrm{R}$ \\
\hline Charadriiformes & (Vanellus superciliosus) & Brown-chested lapwing & (C) \\
\hline Psittaciformes & Agapornis swinderiana & Black-collared lovebird & (C) \\
\hline \multirow[t]{3}{*}{ Strigiformes } & Otus icterorhynchus & Sandy scops owl & (C) \\
\hline & Bubo leucostictus & Eagle owl & (C) \\
\hline & Lophostrix letti & Owl & (C) \\
\hline Caprimulgiformes & Caprimulgus batesi & Bates's nightjar & (C) \\
\hline Trogoniformes & Apaloderma aequatoriale & Trogon & (C) \\
\hline Caraciiformes & Bycanistes cylindricus & Hornbill & (C) \\
\hline \multirow[t]{12}{*}{ Passeriformes } & Campephaga lobata & Ghana cuckooshrike & (C), V \\
\hline & (Baeopogon clamans) & Greenbul & (C) \\
\hline & (Chlorocichla laetissima) & Joyful greenbul & (C) \\
\hline & Phyllastrephus lorenzi & Sassi's olive greenbul & $(\mathrm{NT})$ \\
\hline & (Zoothera princei) & Prince's ground-thrush & (C) \\
\hline & Hyliota violacea & Violet-backed hyliota & (C) \\
\hline & Muscicapa olivascens & Olivaceous alseonax & (C) \\
\hline & Platysteira blissetti & Blissett's wattle-eye & (C) \\
\hline & Platysteira tonsa & White-spotted wattle-eye & (C) \\
\hline & Terpsiphone bedfordi & Bedford's crested monarch & $(\mathrm{NT})$ \\
\hline & Ploceus aureonucha & Golden-naped weaver & (I), $\mathrm{R}$ \\
\hline & Ploceus dorsomaculatus & Weaver & (C) \\
\hline
\end{tabular}

Status follows Groombridge (1993) except in parentheses, where it follows Collar and Stuart (1985).

V, Vulnerable; R, Rare; I, Indeterminate; K, Insufficiently Known; NT, Near Threatened; C, candidate as Near Threatened.

For mammals, 1 represents species completely protected under Zaïre Law 82-002 (illegal to kill, hunt, capture, disturb or follow the species).

Bird species recorded just outside the OWR are listed in parentheses but are assumed to occur in the OWR. 
Changing land-use practices of the BaMbuti

Traditionally, the BaMbuti have lived a nomadic existence in the Ituri Forest and have probably exploited natural resources in a sustainable fashion. As Bantu populations have increased, the BaMbuti have become more dependent on trade with them. In some instances, BaMbuti are now hunting game for Bantu commercial exploitation, which will have a greater impact on species populations than traditional hunting. In the northern regions of the OWR, missionary projects are encouraging BaMbuti to abandon traditional land-use practices and cultivate fields. The BaMbuti should be allowed to continue their traditional life-style within the OWR, but it is clear that their changing and evolving use of resources requires some degree of monitoring and regulation to ensure the reserve remains intact.

\section{Gold camps}

Numerous camps have been established within the OWR by people illegally prospecting for gold. Prospectors clear forest, hunt game and cause significant disturbance to reserve ecosystems. It is difficult to evict camp inhabitants owing to inadequate numbers of IZCN personnel and the high-powered people often supporting the trade.

\section{Public discontent}

Local communities perceive the OWR to be a restriction to their traditional land-use rights. Lack of information and public awareness has fuelled speculation about the restrictions imposed. Many people accepted the creation of the OWR on the condition that they would benefit from associated development projects.
Figure 2. Map of the OWR. Numbers represent proposed locations for IZCN outposts. 1, Epulu; 2, Adusa; 3, Agama/Ngayu; 4, Machinga; 5, Mamba/Nepoko confluence; 6 , Embanzane;

7, Andudu; 8, Nbangupanda;

9, Nduye; 10, River Epulu;

11, Banana; 12, Moto-moto.

(C) $1997 \mathrm{FFl}$, Oryx 31 (1), 49-58

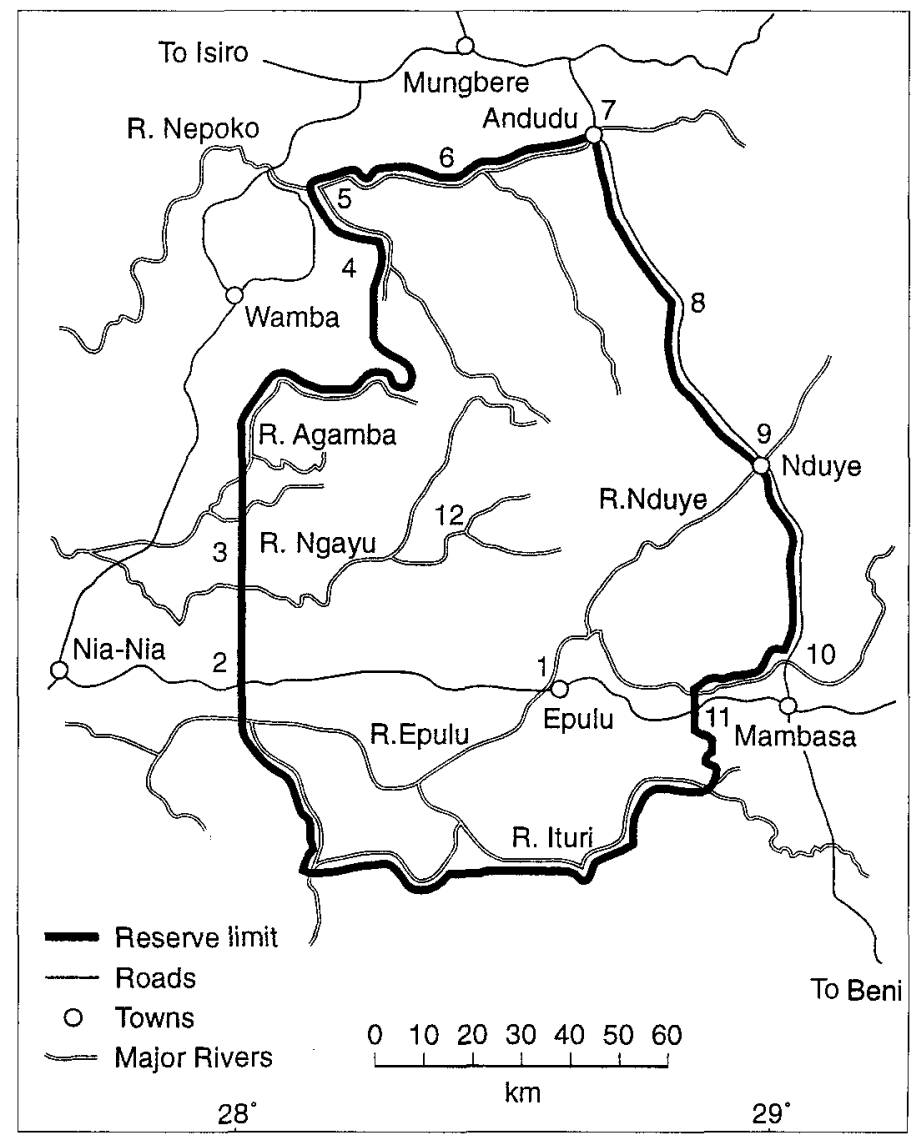


The absence of any such projects outside Epulu has compounded the discontent. In some areas there is fear of the guard force, which may result from people confusing IZCN with other paramilitary organizations. The continued disruption of agriculture by wildlife species such as baboon Papio anubis, bush pig Potamochoerus porcus and elephant further alienates the population from reserve authorities. If public discontent continues, many reserve management activities will be impractical or ineffective.

\section{IZCN capacity}

Largely due to the poor state of the national economy, IZCN lacks sufficient personnel, equipment and infrastructure to manage the OWR effectively. The IZCN force comprises just 39 guards; one for every 35,200 ha. Guards lack suitable clothing, such as waterproofs, and field equipment, such as tents and rucksacks. Most of the station's firearms do not function and there is no communication link between mobile forces. Staff salaries are extremely low (a guard receives the equivalent of less than \$USO.2 per month) and accommodation is available to only a few individuals. An absence of patrol posts outside Epulu means that IZCN activity is generally restricted to the south of the reserve. Only two four-wheel-drive vehicles provide transport for the whole IZCN force, whose mobility is further restricted by roads that are frequently impassable in the wet season. The IZCN's problems are compounded by centralized management systems that require much of the station's decision-making to be approved by the Direction Général in Kinshasa, an often slow and inefficient process. The IZCN has no system of planning, monitoring or evaluating its activities. Overall, therefore, the capacity of IZCN to manage the OWR is severely limited.

\section{Conservation recommendations and priority management actions}

\section{Community participation in reserve management}

It is commonly perceived that for effective conservation management, particularly in tropical forests, local communities must have an active role in decision-making processes (e.g. Hough, 1988; IUCN/UNEP/WWF, 1991; Poore and Sayer, 1991; Brown and WyckoffBaird, 1992; BSP, 1993). Therefore, IZCN and supporting NGOs need to ensure that there is a two-way dialogue with all elements of the communities living in and around the OWR, and that these communities are fully integrated into reserve management systems. Small-scale rural development projects might increase local participation as well as improving peoples' living standards. Emphasis should be placed on empowering people as much as possible to take active and effective responsibility for management of their own resources. One caveat associated with an emphasis on sustainable use and rural development is the need to ensure that the conservation objectives and protection mechanisms for the reserve are not neglected (see e.g. Robinson, 1993; Oates, 1995).

In order to offer a forum for the exchange of information and to integrate the population into reserve management, a system of local consultation committees is being established in groups of villages around the OWR. In areas where committees have become established they are proving effective in providing an interface between IZCN and the community and it is hoped they will be expanded further.

\section{Immigration control}

The most important areas in which immigration must be reduced are the settlements along the Nia-Nia-Mambasa road and the Andudu-Mambasa road (Figure 2). Reserve authorities need to discuss the issue of immigration with community representatives to gain a mutual understanding of the problems and to identify potential solutions. Immigration control will only work if the communities themselves want it to work, understand the reasoning behind it, and identify with the advantages it bestows on their communities. An associated education and public awareness programme is therefore essential. 
Immigrants trying to establish themselves in a village have to gain permission from community leaders. One method of control might be for IZCN to negotiate agreements with leaders and consultation committees, which link rural development aid with a commitment by the community to help reduce immigration. Similarly, following a pilot study in Epulu, a system of zonation could be created within specific settlements to define 'village green zones' in which new building activity or tree-felling is prevented. Future evacuation by IZCN of people from gold camps will also remove the incentive for some immigrants to stay in the reserve.

\section{IZCN capacity building}

The capacity of IZCN to manage the OWR effectively needs to be improved in a number of ways.

1 Reserve management is complicated by contradictory or ambiguous legislation. Problem aspects of the law should be reviewed and potential solutions discussed with the IZCN Direction Général and the Ministry of the Environment.

2 New outposts are required to provide IZCN with bases around the OWR. Adequate accommodation needs to be provided for all personnel. When a system of immigration control is operational, roads and bridges need to be improved.

3 Additional guards, assistant conservators and administrative staff need to be employed to provide enough personnel to cover the entire reserve. Improved training opportunities should be provided for all staff.

4 A communication system and more vehicles are required. Guards need adequate clothing and field equipment. Antipoaching patrols should be organized more effectively to evict gold camps and incorporate a system for monitoring resources and human activities.

5 Capacity-building technical assistance is required from NGOs to help IZCN establish a coherent management system. Improved efficacy could be attained through greater managerial and financial autonomy from Kinshasa and an emphasis on planning, monitoring and evaluation. It is proposed that IZCN forms a more formal management committee, with assisting NGOs and community representatives, to plan, implement and evaluate annual work plans based on priority management actions and the expected level of funding. These plans will help to define and adapt time frames and maintain a realistic flexibility in changing ecological, socio-economic, political and financial situations.

\section{Zoning system}

There is urgent need to establish an effective, multiple-land-use zoning system in the OWR to improve resource management by controlling and monitoring exploitation. Four types of zones are proposed.

1 Subsistence Zones. These zones will be located around settlements. Restrictions on cultivation or commercial hunting will still exist to maintain the integrity of the forest, but these will be limited to allow continued subsistence activities, such as limited cultivation, hunting of non-protected game species, and exploitation of plant products.

2 Green Zones. These zones will be located on the periphery of the OWR to provide areas of undisturbed forest between Subsistence Zones. Any form of tree-felling or cultivation will be forbidden but subsistence hunting will be permitted.

3 Conservation Zone. When Subsistence Zones and Green Zones have been delimited around the periphery of the OWR with the collaboration and agreement of the population, the remaining core area will represent the Conservation Zone. This must be more strictly protected to safeguard faunal and floral communities. A management strategy for this zone cannot be defined on available information and an intensive research project is urgently required to establish the distribution of people and settlements, the distribution of faunal and floral communities, and the level and impacts of resource use.

4 Integral Zone. On completion of the study, management options must be proposed. These should consider the feasibility of part of the Conservation Zone being defined as an 
Integral Zone to provide full protection for a reservoir of faunal and floral species. When determining various management options, the rights of indigenous people to continue sustainable resource use must be considered.

Communities have to be involved with every stage of the conception, implementation and management of the zoning system, which could be discussed and defined at consultation committee meetings. When boundary limits are mapped, reserve authorities need to draw up management agreements. These need to be formal documents, signed by community leaders, binding their communities to uphold various activities in return for assistance with development projects. Each agreement will need to define: zone boundaries within the given community; permitted and restricted activities within these zones; conservation actions that the community will undertake (e.g. towards rationalizing immigration and commercial hunting); development aid that the community will receive.

Where adverse human impacts on reserve ecosystems jeopardize management objectives or an inadequate area is available for the rational subsistence of a stable human population, zone limits will need to be altered. In these instances, management agreements will have to be renegotiated and zone limits redefined.

\section{Rural development}

Integrated Conservation and Development Projects (ICDPs) aim to improve biodiversity conservation in protected areas while improving the quality of life of people in surrounding communities (Brown and Wyckoff-Baird, 1992; Wells et al., 1992). An ICDP approach is advocated for management of the OWR for several reasons. Poor communities with low living standards are often dependent on shortterm, non-sustainable resource-use techniques. If development projects stimulate improvements in, for example, wealth, education and health care, they will help empower people to make more rational decisions on land use. Improved road systems, for example, can increase opportunities for people to diversify their income-generating activities away from a reliance on natural resource exploitation. Furthermore, development projects offer palpable indicators of the advantages of the reserve to communities and ensure that the population feels integrated into reserve management, and the economic and environmental benefits associated with it. They also compensate people for restricted access to certain resources and should improve relations between the population and reserve authorities. One potential negative effect of such rural development is an increase in immigration, with people moving in to the area to take advantage of the higher standard of living (see e.g. Oates, 1995). An improved road system can also improve access for poachers and loggers. These problems might be regulated if the management agreements between IZCN and communities specify the immigration and poaching control mechanisms associated with the development aid.

At every stage in the design and implementation of development projects, community participation is essential. However, development aid must be associated with conservation action; community compliance with reserve management objectives must be a prerequisite of receiving aid. Local people should be incorporated into development project management to ensure sustainability. The aim is therefore to increase community empowerment and self-sufficiency in improving living standards, while attaining conservation goals. Extensive awareness programmes are also imperative.

'Linking conservation and development objectives is ... extremely difficult' (Brandon and Wells, 1992). All development projects in the OWR must be carefully planned and monitored to ensure that mistakes identified elsewhere (Brandon and Wells, 1992; Wells et al., 1992) are not repeated. Development requirements already identified by local people include schools, dispensaries and road repairs.

\section{Education and research}

The WWF and GIC initiated education and public awareness programmes in the Ituri be- 
fore the OWR was created. A larger programme needs to be developed throughout the reserve to communicate with communities, increase people's understanding of conservation issues, and assuage unsubstantiated fears and misconceptions.

There is inadequate information to predict the environmental and socio-economic impact of resource use and management actions in the OWR. Also, no data are available to assess sustainable exploitation levels in Subsistence Zones and Green Zones. An expanded programme of biological and socio-economic research and monitoring is required to provide a basis for improved reserve management. Although many projects are liable to be organized by NGOs, training and management opportunities must be provided for Zairean nationals.

\section{The future}

Conservation objectives in the OWR will be fulfilled only if there is a concerted effort on the part of IZCN and NGOs to implement the management guidelines (IZCN/WWF, 1994). Adequate long-term funding is obviously a necessary prerequisite for conservation action, but any conservation initiative in Zairre has to take account of the country's political and economic instability. Previous grants from development agencies were implemented successfully in the Ituri and international funding continues to support conservation projects in other Zairean protected areas. National instability is unlikely to affect such programmes if they are managed directly by a competent NGO on site.

The IZCN and supporting NGOs continue to instigate temporary, short-term schemes to maintain essential management systems in the OWR. However, only long-term funding and the full implementation of the management guidelines will maintain the integrity of this globally important rain-forest reserve. This will require considerably more financial resources than those currently available to IZCN and the NGOs active in the OWR. Therefore, the management guidelines need to be used as

(C) $1997 \mathrm{FFl}$, Oryx, 31 (1), 49-58 a basis on which to develop a comprehensive funding proposal for submission to donor agencies. Options for funding include a substantial grant from a source such as the UN Global Environment Facility, or one of the donor organizations already active in Zaïre. Funds could be either sourced directly or invested in a trust fund and the accrued profits used for reserve management.

Until such time as long-term funding is secured, the Okapi Wildlife Reserve will remain a cause for concern.

\section{Acknowledgements}

Management guidelines for the OWR were produced by WWF International under the direction of IZCN with input from The Wildlife Conservation Society (WCS) and Gilman Investment Company (GIC). In Zaïre we are especially grateful for the help and advice of the following: Mankoto ma Mbaelele (Director General, IZCN, now with UNESCO); Conservator Mushenzi and Conservator Mubalama (IZCN); Roy Buhendwa Chibombe and Benoît Kambale Kisuki (formerly WWF Education Programme, Epulu); Bryan Curran, John Hart and Terese Hart (WCS); Karl Ruf (GIC) and Jean Nlamba (GIC/IZCN). The views expressed here do not necessarily reflect the policy of WWF International.

\section{References}

Alers, M.P.T., Blom, A., Sikubwabo Kyengo, C., Masunda, T. and Barnes, R.F.W. 1992. Preliminary assessment of the status of the forest elephant in Zaïre. African Journal of Ecology, 30, 279-291.

Brandon, K.E. and Wells, M. 1992. Planning for people and parks: design dilemmas. World Development, 20, 557-570.

Brown, M. and Wyckoff-Baird, B. 1992. Designing Integrated Conservation and Development Projects. Biodiversity Support Program, Washington DC, USA.

BSP. 1993. African Biodiversity: Foundation for the Future. A Framework for Integrating Biodiversity Conservation and Sustainable Development. Biodiversity Support Program, Washington DC, USA.

Collar, N.J. and Stuart, S.N. 1988. Key Forests for Threatened Birds in Africa. ICBP Monograph No. 3. ICBP, Cambridge, UK.

Curran, B. 1992. Appraisal of the Okapi Wildlife Reserve Management Plan. Unpublished report to the World Bank, Washington DC, USA.

Doumenge, C. 1990. La Conservation des Ecosystèmes 
Forestiers $d u$ Zaire. IUCN Tropical Forest Programme, IUCN, Gland, Switzerland.

Grainger, A. 1993. Controlling Tropical Deforestation. Earthscan Publications Ltd, London, UK.

Groombridge, B. (ed.) 1993. 1994 IUCN Red List of Threatened Animals. IUCN, Gland, Switzerland and Cambridge, UK.

Harako, R. 1976. The Mbuti as hunters: a study of ecological anthropology of the Mbuti pygmies. Kyoto University African Studies, 10, 37-99.

Hart, J.A. and Hart, T.B. 1988. A summary report on the behaviour, ecology and conservation of the okapi (Okapia johnstoni) in Zaïre. Acta Zoologica et Pathologica Antverpiensia, 80, 19-28.

Hart, J.A., Hart, T.B. and Thomas, S.C. 1986. The Ituri Forest of Zaire: primate diversity and prospects for conservation. Primate Conservation, $7,42-44$.

Hart, T.B. 1985. The ecology of a single-species-dominant forest and of a mixed forest in Zaïre, Africa. PhD thesis, Michigan State University, East Lansing, USA.

Hough, J.L. 1988. Obstacles to effective management of conflicts between national parks and surrounding human communities in developing countries. Environmental Conservation, 15, 129-136.

IUCN/UNEP/WWF. 1991. Caring for the Earth. A Strategy for Sustainable Living. IUCN/ UNEP/WWF, Gland, Switzerland.

IZCN/WWF. 1994. Management Guidelines for the Okapi Wildife Reserve, Zaire (ed. P. J. Stephenson). IZCN, Kinshasa, Zaire, and WWF, Gland, Switzerland.

McNeely, J.A., Miller, K.R., Reid, W.V., Mittermeier, R.A. and Werner, T.B. 1990. Conserving the World's Biological Diversity. IUCN, Gland, Switzerland and WRI, CI, WWF-US and the World Bank, Washington DC, USA.

Oates, J.F. 1995. The dangers of conservation by rural development - a case study from the forests of Nigeria. Oryx, 29, 115-122.

Oates, J.F., Gartlan, J.S. and Struhsaker, T.T. 1987. A framework for African rainforest primate conservation. In Primate Conservation in the Tropical Rainforest (eds C.W. Marsh and R.A. Mittermeier), pp. 321-327. Alan R. Liss, Inc., New York, USA.

Peterson, R.B. 1990. Searching for life on Zaïre's Ituri Forest frontier. Cultural Survival Quarterly, 14 (4), $56-62$.
Peterson, R.B. 1991. To search for life: a study of spontaneous immigration, settlement and land use on Zaïre's Ituri Forest Frontier. MA thesis, University of Wisconsin, Madison, USA.

Poore, D. and Sayer, J. 1991. The Management of Tropical Moist Forest Lands. Ecological Guidelines, 2nd edn. IUCN, Gland, Switzerland.

Richter, W. Von, Hart, J., Hart, T., Blom, A., Alers. M.P.T., Germi, F., Minne, R., Smith, K., Smith, F. and Verschuren, J. 1990. Zaire. In Antelopes: Global Survey and Regional Action Plans. Part 3: West and Central Africa (ed. R. East), pp. 126-138. IUCN, Gland, Switzerland.

Robinson, J.G. 1993. The limits to caring: sustainable living and the loss of biodiversity. Conservation Biology, 7, 20-28.

Stuart, S.N. and Adams, R.J. 1990. Biodiversity in Sub-saharan Africa and its Islands. Conservation, Management and Sustainable Use. Occasional Papers of the IUCN Species Survival Commission No. 6. IUCN, Gland, Switzerland.

Thomas, S.C. 1991. Population densities and patterns of habitat use among anthropoid primates of the Ituri Forest, Zaïre. Biotropica, 23, 68-83.

Turnbull, C.M. 1961. The Forest People. Simon and Schuster, New York.

Turnbull, C.M. 1983. The Mbuti Pygmies: Change and Adaptation. Holt, Rinehart and Winston, New York.

Turnbull, C.M. 1986. Survival factors among Mbuti and other hunters of the equatorial African rain forest. In African Pygmies (ed. L. L. Cavalli-Sforza), pp. 103-121. Academic Press Inc, London, UK.

Verschuren, J. 1978. Note sur la distribution geographique et la situation actuelle de l'okapi, Okapia johnstoni. Acta Zoologica et Pathologica Antverpiensia, 71, 15-29.

Wells, M., Brandon, K. and Hannah, L. 1992. People and Parks: Linking Protected Area Management with Local Communities. The World Bank, Washington DC, USA.

Peter J. Stephenson* and John E. Newby, WWF International, Africa and Madagascar Programme, Avenue du Mont Blanc, CH-1196 Gland, Switzerland.

*Current address: WWF Tanzania Programme Office, PO Box 63117, Dar es Salaam, Tanzania. 